\title{
自主シンポジウム I：青年の理解とその方法論について
}

オーガナイザー

$\begin{array}{ccccc} & \text { 寺 } & \text { 田 } & \text { 晃 (東北大学) } \\ \text { 提案者 } & \text { 久 } & \text { 世 } & \text { 敏 } & \text { 雄 (名古屋大学) } \\ & \text { 佐 } & \text { 藤 } & \text { 克 } & \text { 夫 (宮城教育大学) } \\ \text { 国 } & \text { 眼 } & \text { 真理子 (東京学芸大学) } \\ \text { 坂 } & \text { 田 } & \text { 健 (岐阜大学) }\end{array}$

最初にオーガナイザー（寺田）から，本シンポジゥ ムが, 埼玉大学での自主シンポジゥム「青年心理学の 方法論」の発展であると共に, 青年理解のための方法 として先回に打ち出した 7 方法を 4 方法にまとめ, 科 学研究費による共同研究の成果をも含めて, 方法論と しての総合的な体系化を期する主旨で企画されたとの 説明がなされた。

各提案者の発表内容は，あらまし次のとおりである （各提案者の記述を中心とする）.

久世敏雄：(質問紙調査法的アプローチ)：

青年期は, 人生観確立の時間的余裕をむたない高校 生活の卒業を境に, 勤労青年と大学生の 2 群に分かれ る. 中学生および高校生は, 成長の spurt の時期であ り, 生理的変化に伴なら適応の問題に直面する. 一方, 大学生とそれに続く時期は, 自己と社会との間の緊 張・葛藤に直面する時期である.

いま，かりに $12 ， 3$ 歳から $17 ， 8$ 歳までを青年期 (adolescence)，18，9 歳から 24，5歳〜30 歳までを youth とよぶならば, 青年の理解とは, 2 つの青年期の 分岐点となる人生選択の要因が何であり，その後の人 格形成の過程がいかなるものであるかを明かにするこ ととなる. 換言すれば, 青年期の特徵は何か, youth の 特徵は何かを理解することである.

これらの 2 群の青年を理解するさい, 青年一般を理 解すると同時に，青年個人を理解することが必要であ る. 青年一般を理解することは, 研究の狙いが法則定 立的な目的をもつことであり，また，青年個人を理解 することは個性記述的な目的をもつことである. 青年 心理の研究では, この両者のそれぞれの長所を最大限 に生かすことが必要であり，このための方法は，両者 を交互に組合せることである.この組合せの方法には， 青年一般一青年個人一青年一般という3 段階法と青年 個人一青年一般一青年個人といら 3 段階法とがある. 青年心理研究において，このいずれを採用するかは， 研究の目標と関連する.
次に，青年理解にさいしては，発達過程・人格形成 を明かにする視点が重要である. この視点は, 従来, 発達の連続性, 非連続性の問題として提起されてきた。 人間の発達が連続的なものであるか否かは，モデルに よって異なっている．青年期に疾風怒涛の現象がみら れるか否かを明らかにするためには，絽断的研究によ り，同一個人を継続的に追跡することが必要である. このさい, 発達・人格形成の目標が問題となる. 自己 実現を果たし, 自己決定の可能な青年, 無限の潜在的 可能性, 成長可能性に能動的に参加する青年, こらいっ た青年が目標となる．な敃青年の発達・人格形成に関 連して, 行動発達のどの側面を検討するか, いわば行 動の母域を確定することも必要である.

これらの視点から青年の理解に迫るとき，質問紙調 查法的アプローチは, 青年心理研究における 3 段階分 析法において, 青年一般の理解に役立つものである. このアプローチは, 青年一般の理解が実態調查的水準 であれ, 仮説検討的水準であれ, 強力な武器となる.

次に，このアプローチに拀いて，質問紙法を縦断的 に使用することにより, 青年の発達過程を分析するこ とができる.

このように, 質問紙調査法的アプローチは, 青年一 般の理解および発達過程の分析に有効な手段である が, このアプローチでは, 個別理解に迫るデータは得 にくく, このためには, 他の方法, 技術を援用するこ とが必要となる.

佐藤克夫：(実験観察法的アプローチ)：

青年研究は, 青年の行動や意識の実態を把え把する こと,さらにその行動や意識の発達の過程を理解する ことにある.これについては, 端的に質問紙調査法や 面接調查法が有効であるが，それらの方法は，青年の 実態や発達の姿を, 比較的巨視的にとらえるものであ り, しかも研究者主導による方法にはなり得ない。し たがって, 青年の行動や意識の発生に関する因果関係 を理解するといら要請にこたえて，いわゆる実験法が 必要となる.

具体的な方法としては,「語いの認知闘」に関する研 究手続, アイカメラによる「青年の写真鑑賞」の研究 におけるそれがあげられる，われわれは，これまでに 青年を対象とした実験法の研究としてそれらを展開し てきたが，例を後者の研究にとれば，統制された条件 下では, 興味, 関心のない写真には, アイマークの軌 
跡がなく，青年独自のある一定の傾向をとらえること ができた。その意味で，青年の内的な心的活動を，条 件分析的にとらえることは可能であると共に，方法と して有効なものと考えている.

しかしながら，それにしても青年心理学における実 験に, 自然科学でのそれのような完全な条件統制を期 待することはできない。トーメ， $\mathrm{H}$ が述べているよう に，それは，実験法とはいっても，あくまで「観察条 件の統制ががうきく」という域でのものとなろう. 青年の心的活動の特徵を, 仮説検証的にその因果関係 を明確にすることが必要であり，そこに実験観察的ア プローチの意義が方法論として浮上してくるものの, 方法としては, 以上の点に留意することが大切といら ことになろう.

\section{国眼真理子：(指導観察的アプローチ):}

本アプローチは，(1) 青年との直接的なかかわりの 中で, 青年の示す行動の意味を深く追求する, (2) かか わりの過程で, 青年は自己理解を, 研究者は青年理解 を深める, (3) 究極的に青年の自己実現みはかる等を 目的とする.その特質は，(1) 直接的でしかる継続的に 青年とのかかわりをもつ, (2) 青年が持つ問題の解決 を糸口にしてかかわる, (3) 青年のもつ個別理解に基 づいて働きかけ，その働きかけの結果，明らかにされ る事実により個別理解を深める, このサイクルを繰り 返す，(5) 個別理解に基づき,最終的に治療的働きかけ の手掛りとなるような一般法則定立をめざす, (6) 研 究者がチームを構成することによって多面的理解と多 様な働きかけを行らなどの 6 点にある。なお，これら のらち，昨年来更に事例研究を重ねる過程でとりわけ 重要な特質として浮上してきたのが，(1)，(2)および (5) である.

(1)に関していえば, ひとつには青年の行動の変容お よび行動に附与する意味の変容をさぐることができ る，ふたつには青年の提起した問題の本質，背景をた どることができるといら利点がある. (2) の特質は, 青 年自身の自我関与を高める上に欠くことができない． 自我関与といらとき，青年みずからがもつ課題の解決 に関する自我関与と, かかわり合ら人間関係に関する 自我関与とのふたつがあろらが，いずれも青年研究を 進める上で, 妥当な青年理解を行っていく上で, 無視 でさない重要な要因である，本アプローチでは，当面 青年の自我関与を高めるひとつの方策としてこの特 質・方法を用いる. (5) の特質は, 本アプローチの今後 の課題とも言えるが，単に青年について個別的理解を 深めるにとどまらず，いかなる青年に，いかなる事態
でどう働きかけたならば所与の課題解決が可能か, ま たその解決過程での青年の自己実現が可能であるか等 について，治療的な手掛りとも言うべき法則定立をめ ざしていることを意味する.

以上あげた観点・特質により，本アプローチでは， 青年の存在を細かに分断してしまうことなく，全体的 な把握をねらっている。

なお，このよらな青年理解の方法をとるに当たり， われわれは発達の目標としての青年を次のように描 く、すなわちそれは，環境および自己に関する的確な 認知に基づき自己決定が可能な青年であり, 環境に対 し積極的に働きかけていくことができる青年である. 本アプローチでは，この方向をめざし青年とのかかわ りを続けると共に, 青年がみずからこの方向をめざし 始めたときをもって関係終結の基準としている.

最後に, 今後の課題として残されている問題を 2,3 あげる．(1)「自己決定」あるいは「自己実現」とはい かなる状況，事態を意味するのかを更に吟味する，(2) 個別的理解から青年の一般理解へといかにして視野を 払大していくかを検討する，(3) 研究者と青年とのか かわりの中で, 青年自身が気づかない問題をどう自覚 させるかを考える，以上 3 点が，今後本アプローチに より事例研究を重ねる中で検討，吟味されるべき課題 である.

坂田 健：(現象学的フプローチ)：

1. 心理学の科学性 現代の正統派 (自然科学的) 心理学は, 合理性, 客観性を指標とする実証科学をめ ざしている. それは物理学をモデルにして, 複雑な人 間的事象もできるだけ単純な要求に還元する。そこに は，人間をものと本質的に同じものとみる自然科学的 態度がある.

このような方法だけが，心理学的研究法の名に価す るもの, 青年の心にせまるふさわしいものとは思えな い.

2. 現象学的方法このような科学通念についての 信仰を一度疑い, 適切な方法を自覚的に行使しょうと するものである。これまでの経験的心理学は, 常識的 に漠然と理解している概念, 言葉を手がかりとし, こ れらのものが指示している事象の本質を吟味すること がおろそかにされている. 現象学的方法は, 直観的方 法で心理現象の本質にせまり，それを記述しょうとす る. 先入見を排し，経験に与えられるままの具体的事 象へ立ち還り，すべてを問いなおそうとするものであ る.

そのために，さし当たりは次のような点を中心に研 
究を進める.

(1) 志向性 意識（経験）の本質を志向性としてと らえ，意識は必ずあるものについて意識として，己れ のそとに己れならぬあるものを己れの対象としても つ,それをフッサールの言らノェシス（意識すること） と, ノェマ（意識されるもの）といら2つの不可分な 環として経験，心理をとらえようとする.

これは更に心理現象のそれぞれの領域で固有に営ま れている現象の志向性を明らかにし，それらの志向性 に共通の意味方向を見出すことでもある．青年が世界 （生活空間）に向かって何事かを企てようとしている その様態の示す志向性をとらえようとする. それは青 年心理学に目的論的視点をとり入れ，現実の青年の行 動, 経験がどこに向かって進み, 企てられているかを 明かにしようとする。

(2) 全体的, 構造的把握 青年の示す現象とその背 後にある人格的背景とを直観することから全体的構造 特徵をとらえる方向をめざす.

(3) 了解と解积 これまでの青年心理学では, 説明 的方法を解釈と称し，恣意的にこれを行ってきたきら いがある.

解釈学的現象学の解釈は, 解釈に先立ち, 非表明的 に漠然とし了解されていることがらを, 主題的に浮か び上がらせ，明るみに持ちきたし，明らかな概念とし て仕上げることである.

具体的な研究としては，青年の手記，FAT，20 答法 などで得られた材料について，上述のような方法を適 用し，分析を進めている.

以上, 4 提案者の報告を受けて質疑応答に入った．ま ず和田 (日赤) から, 青年を理解する場合に, 時代的・ 社会的な状況把握が必要とされる理由について質疑が あり，久世が，それを受けて，現代青年のおかれてい る社会的背景と, 行動の解析と理解にそれが不可欠な 条件であることを説明した。また高山（秋田大）より， 国眼に対し，「指導観察的アプローチ」が青年研究法の
ひとつであるとしても，そこには臨床心理学の方法と しての意味あいが濃厚であり, したがって方法上, 青 年心理学と臨床心理学との関係ならびに区別をいかに つけるのかとの問いが出された。これに対し国眼は, 同方法と臨床心理学での教育相談との差違を中心とし た特質を再度指摘した（青年とのかかわりをむって青 年を理解するといら点で, 同方法は, 場合によって臨 床心理学をも包含するものであることを強調した， 4 アプローチによる提案は，拈拈むね「方法論」として の陳述を行ったのであったが，続いて西平（山梨大） より, 返田に対し, 青年理解には確かな「方法論」が 根底になくてはならず, したがって「方法論」と「方 法」とが区別されるべきであるが，その点で当該提案 はいずれを強調するむのであるかとの質疑がなされ た.これに対し返田は, 提案の陳述が，たんに技術的 な方法としてではなく、「方法論」をふまえたものであ ると答えた。 また同質疑についてい，そのあと久世， 佐藤, 国眼らが応答し, 西平も再度意見を交換するな ど, 活発な討議が展開された。

西平の質疑は, 本シンポジウムに限らず, 青年研究 の一般としても考虑すべき重要な基礎的事項であった ため, 特にフロアの関心をかい, また松本（東北大） から，第 2 信号系にかかわる視点，教育ならびに発達 （歴史的）の観点に拠して，青年心理一般を検索して いくべき旨など，示唆が提供されたが，時間的な制限 もあって, それぞれの提案について，いわゆる「方法 論」としての理論的な確認は今後に残された。

しかし青年心理学の研究法として，技法と理論とに 一脈の有機的な整理と総合化が得られた点で, 本シン ポジゥムは，きわめて有効かつ意義あるものになった と言えよう。ここでは 4 つの方法論ないしその具体的 な技法がとりあげられたが，今後は，それらを攡して， 青年のある特定の行動的典型を多面的に検討し, 各方 法論ないし方法の内容を一そう深化させていくと共 に, 相互間の体系化を定立することが課題となった。

（寺田 晃） 
Ishii reported from his many years' experience that the important thing in the education including therapy and training for autistic children was to improve the human relationship between therapist and children.

The authors concluded: the therapeutic approach to the behavior handicapped children was discussed among the members, but no integrated conclusion was reached. Perhaps there were among the members some, differences of views on handicapped children. Sufficient study should be given not only to the change of behavior but to the formation of the inner world of the handicapped children, and in the study we should consider a handicapped child as a whole person.

\title{
Independent Symposium I
}

\section{ON UNDERSTANDING ADOLESCENTS AND ITS PSYCHOLOGICAL METHODOLOGY}

\author{
Organizer: A. Terada (Tohoku University) \\ Symposist: T. Kuze (Nagoya University) \\ K. Sato (Miyagi University of Education) \\ M. Kokugan (Tokyo University of Arts And Sciences) \\ T. Sorita (Gifu University)
}

The aim of this symposium was to make clear our problems about methodology of psychology of adolescence, and examine the general systematization among the methods taken up by four symposists.

T. Kuze stressed the significance of the questionnaire method, and clarified that the approach would be quite effective in order to see the behavioral traits of adolescents in general, while presenting some concrete data.

$\mathrm{K}$. Sato emphasized the necessity of the experimental method especially in order to see the causality in behavioral development of adolescents. He pointed out, however, that questionaires and other methods should be used at the same time.

M. Kokugan spoke on the characteristics of directive observational method, and examined the possibility and the significance of understanding adolescents in helping them to solve their urgent and current problems.

$T$. Sorita explained the meaning and the necessity of phenomenological approach to understand the essential traits of behavior by using their notes and other data, and to understand the structure of adolescent personality in general.

After these presentations, A. Terada emphasized that these approaches of methods had to be integrated and much systematized in the future, and commented on some concrete planning. 